\title{
Concurrent Influence of Different Natural Sources on the Particulate Matter in the Central Mediterranean Region during a Wildfire Season
}

\author{
Jessica Castagna $^{1, * \mathbb{D}}$, Alfonso Senatore ${ }^{1} \mathbb{D}$, Mariantonia Bencardino $^{2}$ and Giuseppe Mendicino ${ }^{1}$ \\ 1 Department of Environmental Engineering, University of Calabria, 87036 Rende (Cosenza), Italy; \\ alfonso.senatore@unical.it (A.S.); giuseppe.mendicino@unical.it (G.M.) \\ 2 CNR-Institute of Atmospheric Pollution Research, 87036 Rende (Cosenza), Italy; bencardino@iia.cnr.it \\ * Correspondence: jessica.castagna@unical.it
}

Citation: Castagna, J.; Senatore, A.; Bencardino, M.; Mendicino G. Concurrent Influence of Multiple Natural Sources on the Particulate Matter in the Central Mediterranean Region during a Wildfire Season. Atmosphere 2021, 12, 144. https:// doi.org/10.3390/atmos12020144

Received: 31 December 2020 Accepted: 18 January 2021 Published: 23 January 2021

Publisher's Note: MDPI stays neutral with regard to jurisdictional clai$\mathrm{ms}$ in published maps and institutional affiliations.

Copyright: (C) 2021 by the authors. Licensee MDPI, Basel, Switzerland. This article is an open access article distributed under the terms and conditions of the Creative Commons Attribution (CC BY) license (https:// creativecommons.org/licenses/by/ $4.0 /)$.

\begin{abstract}
Wildfire occurrence and severity in the Mediterranean region during the summer season is increasing, being favoured by climate change-induced conditions (i.e., drought, heatwaves). Moreover, additional natural sources frequently impact this region, particularly Saharan dust intrusions. This study focuses on the combined effect of wildfires and Saharan dust on the air quality of the central Mediterranean Basin (CMB) during 2017, an exceptional year for forested burned areas in southern Italy. The annual behaviors of $P M_{2.5}, P M_{10}, C O$, benzene, and benzo(a)pirene measurements that were recorded at a rural regional-background station located in southern Italy, highlighted a concentration increase during summer. Both Saharan dust and wildfire events were identified while using Navy Aerosol Analysis and Prediction System (NAAPS) model maps, together with high-resolution Weather Research and Forecast-Hybrid Single-Particle Lagrangian Integrated Trajectory (WRF-HYSPLIT) back-trajectories. Additionally, Visible Infrared Imaging Radiometer Suite (VIIRS) satellite detections were considered to establish the enrichment of air masses by wildfire emissions. Finally, the occurrence of these natural sources, and their influence on particulate matter, were examined. In this case study, both $P M_{2.5}$ and $P M_{10}$ exceedances occurred predominantly in conjunction with wildfire events, while Saharan dust events mainly increased $P M_{10}$ concentration when overlapping with wildfire effects.
\end{abstract}

Keywords: wildfires; saharan dust; natural sources; central mediterranean; particulate matter

\section{Introduction}

The impact of Mediterranean wildfires involves several sectors entailing environmental, human, and economic losses. Over 40,000 fires per year were reported between 2010 and 2016 in European countries bordering the Mediterranean Basin [1]. Such a tremendous impact can be related to the increasing occurrence and intensity of extreme meteorological phenomena, such as droughts and heatwaves, which are expanding wildfire danger, implying rapid spread, intense burning, long-range spotting, and unpredictable shifts [2,3]. Nevertheless, the most concerning aspect that is related to wildfires is the adverse public health effect that is caused by the exposure to biomass burning emissions, which causes every year hundreds of thousands of deaths worldwide (i.e., 339,000 people annually, estimated for the period 1997-2006 by [4]). Indeed, the main compounds emitted by wildfires, including aerosol (i.e., fine and coarse particulate matter, PM) and trace gases, such as carbon monoxide $(\mathrm{CO})$, methane $\left(\mathrm{CH}_{4}\right)$, nitrous oxide $\left(\mathrm{N}_{2} \mathrm{O}\right)$, nitrogen oxides $(\mathrm{NOx})$, and volatile organic carbon (VOC) [5], appeared to have an adverse effect on all-cause mortality and respiratory morbidities, like asthma, chronic obstructive pulmonary disease (COPD), bronchitis, and pneumonia [6-8]. This global public health issue is growing, particularly in areas where large and widespread wildfires are becoming an increasing concern [2,9]. 
In addition to wildfire emissions, the Saharan dust (SD) events also contribute to worsening air quality in Europe and affect the mortality rate of exposed people [10]. Both of these sources are considered as natural, although wildfires are mainly humancaused [11]. SD can easily reach the Mediterranean countries [12], but it can also be transported and distributed across the planet [13] with different frequencies of occurrence and with consequent influence on PM concentration levels, depending, among many factors, on the proximity of the source areas $[12,14]$. While the SD episodes worldwide are rare and of low intensity $[14,15]$, they are frequently recorded in European Mediterranean countries, strongly affecting PM concentrations [8,12,16-20]. Many studies observed that SD events often cause the exceedance of the $P M_{10}$ limits [12] that were established by the European Air Quality Directive (EU 2008/50/EC).

In order to establish the source-receptor relationship of air pollutants, tracing the transport between the geographical origin of air masses and the measurement site, several models are usually applied [21-24]. In particular, analysis of backward trajectories enables identifying stationary and mobile emission sources of both natural and anthropic origin [24]. Among backward trajectory models, one of the most applied is Hybrid Single-Particle Lagrangian Integrated Trajectory (HYSPLIT), whose development was improved during the last 30 years [25]. Nonetheless, the HYSPLIT model is affected by uncertainties due to spatial resolution. In order to minimize this drawback, several modelling strategies were adopted enhancing the horizontal spatial resolution of meteorological fields, especially in territories with complex orography, as confirmed by the application of HYSPLIT with high-resolution mesoscale models [25], such as the Weather Research and Forecast (WRF) model [26].

Although the Italian wildfire extension trend is decreasing [1], 2017 was a remarkable year that was characterized by exceptionally wide burned forest areas in the driest and hottest southern portion of the country, particularly in the Calabria region (southern Italy), where the number and extent of fires were the highest in the previous ten years [27]. This study analyzes the combined impact of natural sources, such as Saharan dust and wildfires that occurred during 2017, on the air quality measurements of a regional/rural background station in Calabria. Saharan dust intrusions were revealed following the European guidelines [28], which suggest the evaluation of backward trajectories and the use of the Navy Aerosol Analysis and Prediction System (NAAPS, [29]) aerosol model. Furthermore, WRF simulations with a horizontal resolution equal to $10 \mathrm{~km}$ were coupled to the HYSPLIT model in order to calculate more accurate back-trajectories [30]. The influence of wildfires was evaluated considering the ground-based measurements of particulate matter $\left(P M_{2.5}\right.$ and $\left.P M_{10}\right)$ jointly to some biomass burning markers, such as carbon monoxide $(\mathrm{CO})$, benzene $\left(\mathrm{C}_{6} \mathrm{H}_{6}\right)$, and benzo(a)pyrene $(\mathrm{BaP})[31,32]$. The analysis of these parameters and the evaluation of the high-resolution Weather Research and Forecast-Hybrid Single-Particle Lagrangian Integrated Trajectory (WRF-HYSPLIT) backtrajectories intercepting the satellite Visible Infrared Imaging Radiometer Suite (VIIRS) fires allowed for establishing wildfires influence [30]. Finally, PM variability was analyzed after identifying the natural influence (Saharan dust and/or forest fires) impacting southern Italy. In particular, events with high PM concentrations were examined.

This paper is organized into four sections. After this Introduction, in Section 2, the sampling station with its instrumentation, the satellite data, the WRF and WRF-HYSPLIT models, and the additional tools used, are described. In Section 3, the results achieved are reported together with the related discussion. Finally, Section 4 is dedicated to the Conclusions. 


\section{Materials and Methods}

\subsection{Study Area, Sampling Station and Instrumentation}

The study addresses the most southern Italian region, excluding islands, i.e., Calabria, which is a peninsula of approximately $15,000 \mathrm{~km}^{2}$, stretching out into the central Mediterranean $\left(39^{\circ} \mathrm{N}-16.5^{\circ} \mathrm{E}\right)$, which is surrounded by the sea to the east, the west, and the south, and only approximately $500 \mathrm{~km}$ from the northern African (Tunisia) coasts.

The background station selected for the analysis is the Mammola station $\left(38.39092^{\circ} \mathrm{N}-\right.$ $16.23452^{\circ} \mathrm{E}$ ), a rural regional background station managed by the Regional Agency for the Environmental Protection of the Calabria Region (ARPACAL, [33]) (Figure 1). It belongs to the regional air monitoring network, which includes 20 stations. In particular, this station is placed in the National Park of Aspromonte, in the south of the region, in a hilly coastal area, approximately $25 \mathrm{~km}$ from the Ionian Sea (eastward) and approximately $35 \mathrm{~km}$ from the Tyrrhenian Sea (westward). A rural regional station is characterized by a distance from any source in a range from 10 to $50 \mathrm{~km}$, according to the European Environmental Agency [34]. Because of its strategic position, the recorded air quality is representative of the pollutant background concentrations, without any industrial or urban influence, and is also able to record fluctuations in pollutant concentrations mainly due to long-range transport or associated with the variability of natural sources, such as the Saharan dust and wildfires. At Mammola station, particulate matter, i.e., $P M_{2.5}$ and $P M_{10}$, is monitored through the analyzer model Environnement MP 101M, based on the absorption of the beta-ray of the sample collected on the fiber tape. The instrument has a lower detectable limit of $0.5 \mu \mathrm{g} \mathrm{m}^{-3}$. The time sampling for $P M_{2.5}$ and $P M_{10}$ was set to $24 \mathrm{~h}$. The $\mathrm{CO}$ measurements are conducted through the analyzer Model Environnement CO 12M, whose measuring principle is the infrared light absorption of the sample gas. The lower detectable limit $(2 \sigma)$ is equal to $50 \mathrm{ppb}$. Otherwise, $\mathrm{C}_{6} \mathrm{H}_{6}$ is measured while using BTX model Synspec Syntech GC 955. The lowest detection level for $\mathrm{C}_{6} \mathrm{H}_{6}$ is $0.1 \mu \mathrm{g} \mathrm{m}^{-3}$ (0.03 ppbV), while the standard range is $0-20 \mathrm{ppbV}$. $\mathrm{CO}$ and $\mathrm{C}_{6} \mathrm{H}_{6}$ both had hourly time resolutions. Finally, the $\mathrm{BaP}$ is determined following the UNI EN 15549:2008 standard, which provides for the sampling of $P M_{10}$ on quartz filters, on a daily basis, and subsequent extraction with solvent. The content in $\mathrm{BaP}$ is then evaluated by gas chromatographic methods with mass spectrometry (GC-MS). After the quality control (QC), data are shared with the European Environment Agency (EEA) within the AirBase Network [35]. This study analyzes the $P M_{2.5}, \mathrm{PM}_{10}, \mathrm{CO}, \mathrm{C}_{6} \mathrm{H}_{6}$, and $\mathrm{BaP}$ measurements in 2017. Furthermore, a focus on the summer of the same year is conducted.

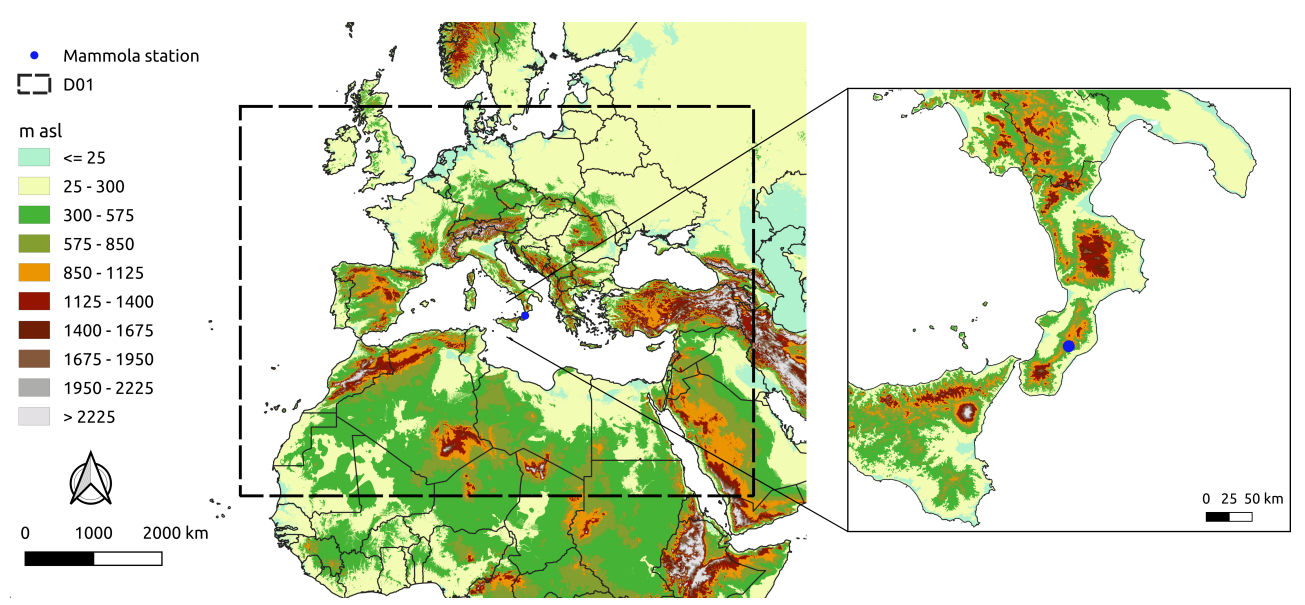

Figure 1. Geographical location of the rural regional background Mammola station (blue point) and Weather Research and Forecast (WRF) domain (dashed line). 


\subsection{Satellite Data}

The VIIRS fire satellite data were used to implement a wildfire dataset for the centralwestern Mediterranean region in summer 2017. The VIIRS fire detection technique is based on the principle of thermal anomalies [36]. The VIIRS sensor was launched aboard the joint NASA/NOAA Suomi National Polar-orbiting Partnership (Suomi NPP) and NOAA-20 satellites in 2012. Both of the satellites cross the equator two times per day, in particular, the Suomi NPP at approximately 1:30 p.m. in the ascending node and 1:30 a.m. in the descending node, while the NOAA-20 at approximately 1:30 p.m. and 1:30 a.m., in the ascending and the descending node, respectively. VIIRS has 21 channels, five high-resolution Imagery channels (I-bands) with a nominal resolution of approximately $350 \mathrm{~m}$, and 16 moderate resolution channels (M-bands), and a Day/Night Band (DNB). The validated VIIRS data are the coordinates of the center of fire pixel, the brightness temperature, the actual fire pixel size, the acquisition date and time, the confidence level, fire radiative power (FRP), and the fire type ("presumed vegetation", "active volcano", "other static land source", and "offshore"). In this study, only the detections classified as "presumed vegetation" were considered.

\subsection{WRF Model and WRF-HYSPLIT Back-Trajectories}

The meteorological variables were simulated through the Advanced Research WRF (ARW) model, version 4.1. The simulation started on the 25th of May (with a spin-up time of one-week before the first day of analysis, i.e., the 1st of June) and ended on the 17th of September. The WRF model has been widely applied in order to realize forecasts and reanalysis simulations of weather and climate conditions in Calabria and to evaluate the hydrological impact (i.e., [37-40]). Operational high-resolution weather forecasts for the Calabria region, realized while using the WRF downscaling, are currently provided by the Department of Environmental Engineering of the University of Calabria [41]. A single domain was used to evaluate both wildfire and SD intrusion effects on the particulate matter increase, including the whole Mediterranean basin and northern Africa $\left(17.59513^{\circ}\right.$ $-56.72691^{\circ} \mathrm{N},-21.25597^{\circ}-46.38397^{\circ} \mathrm{E}$, Figure 1). The domain had a horizontal resolution of $10 \mathrm{~km}$ ( $576 \times 437$ grid points), 44 atmospheric layers with a pressure top of 50-hPa (about $20,000 \mathrm{~m}$ ), and a time step of $60 \mathrm{~s}$. The physical parameterization of the model was the same as the outermost domain of some high-resolution simulations that were already performed in the central Mediterranean area $[30,42]$. Because the horizontal resolution did not permit explicitly solving convection, the cumulus parameterization scheme of Tiedtke [43] was switched on. The boundary and initial conditions were provided by the ERA5 global dataset having a horizontal resolution of approximately $30 \mathrm{~km}$ and 137 vertical atmospheric levels (up to $80 \mathrm{~km}$ ). In order to analyze the influences of the different sources on the receptor site (i.e., the Mammola station), the Hybrid Single-Particle Lagrangian Integrated Trajectory Model (HYSPLIT) developed by the NOAA's Air Resources Laboratory, was used $[25,44,45]$. HYSPLIT is a tool largely employed for identifying backward trajectories, which are calculated while using the Lagrangian approach $[19,20,46,47]$. This model is available at Ready online system [48]. The online tool "Hysplit Ready System" [49] was also created for this purpose, while using different spatial resolutions, namely $2.5^{\circ}$ (NCEP/NCAR Reanalysis, from 1948 to present day), $1^{\circ}$ (GDAS dataset, from 2006 to present day), $0.5^{\circ}$ (GDAS dataset, from 09/2007 to 06/2019), and $0.25^{\circ}$ (GFS dataset, from $06 / 2019$ to present day). However, these resolutions do not fit the complex orography of the Calabrian peninsula well, which is long and narrow, with steep mountains very close to the sea, producing an error due to the difference between model and real topography. For this reason, the HYSPLIT back-trajectories were calculated with a driving meteorological dataset that was derived from a mesoscale model, which can provide more accurate information in a complex territory [50-52]. In particular, the $10 \mathrm{~km}$-resolution WRF meteorological fields were used as input to HYSPLIT, after the conversion from NetCDF to the HYSPLIT compatible ARL format while using the conversion program "arw2arl" [49]. The Hysplit model used in the study was PC-based and version 4.2.0. Moreover, the uncertainty of an 
individual trajectory can be evaluated by calculating a trajectory ensemble through the application of offsetting of the meteorological data, for example, considering the shifts of one meteorological grid point along each horizontal direction (i.e., nine horizontal directions) and 0.01 sigma units up and down along the vertical [49]. In this way, while the history of a single path trajectory can be limiting, a group of 27 trajectories covers a larger area that can ensure the inclusion of the possible pollutant source.

\subsection{NAAPS Maps}

The potential impact of dust and/or smoke intrusion over the Mammola sampling station was confirmed through the NAAPS model, which was developed by the Naval Research Laboratory (NRL). This model of air pollution uses global meteorological fields from the Navy Operational Global Atmospheric Prediction System (NOGAPS) and deducts dust, smoke, sea salt, and anthropogenic/biogenic (labeled as sulfate) fine mode particles, according to the atmospheric optical thickness (AOT) [53,54]. The spatial resolution is $1^{\circ}$ and a new simulation restarts every $6 \mathrm{~h}$. The resulting maps can be downloaded at the NAAPS's website [55].

The dust surface concentration NAAPS maps permit the confirmation of the dust mineral composition related to the total PM collected at the Mammola station. These maps are largely considered to identify the Sarahan intrusions reaching the European countries [18]. However, in order to avoid any other types of dust origin (for example, resuspension dust), the analysis of backward trajectories is always mandatory. Furthermore, the NAAPS maps of smoke surface concentration show the potential presence of aerosol with a biomass burning composition. In this way, the dispersion of a plume originated by biomass burning, as wildfires, can be evaluated.

\section{Results}

\subsection{Temporal Trend of Ground-Based Measurements}

During 2017, the measurements of particulate matter at the Mammola rural regional background station recorded overall low concentrations, thus confirming the classification of this sampling station located far from local sources (Figure 1) [56]. Indeed, the annual mean value of $P M_{10}$ was $14.9 \mu \mathrm{g} \mathrm{m}^{-3}$ (median: $12.2 \mu \mathrm{g} \mathrm{m}^{-3}$ ), while for $P M_{2.5}$ it was $9.5 \mu \mathrm{g} \mathrm{m}^{-3}$ (median: $7.6 \mu \mathrm{g} \mathrm{m}^{-3}$ ). The annual variability highlighted a significant increase during the summer period for both granulometric sizes. $P M_{2.5}$ concentrations showed higher values during the summer months, especially in July, when the maximum monthly mean and median values were recorded $\left(21.2 \mu \mathrm{g} \mathrm{m}^{-3}\right.$ and $16.0 \mu \mathrm{g} \mathrm{m}^{-3}$, respectively) (Figure 2a). Similarly to the $P M_{2.5}$ trend, the behavior of $P M_{10}$ concentrations was characterized by a significant increase during summer. In the same way as $P M_{2.5}$, the highest $P M_{10}$ monthly mean and median concentrations, equal to $26.1 \mu \mathrm{g} \mathrm{m}^{-3}$ and $22.5 \mu \mathrm{g} \mathrm{m}^{-3}$, respectively, were recorded during July. However, another moderate peak in concentration for both PM sizes was observed during the winter months, which may be explained by domestic heating [57].

The recorded annual CO mean value was $0.18 \mathrm{mg} \mathrm{m}^{-3}$ (median: $0.17 \mathrm{mg} \mathrm{m}^{-3}$ ). The $\mathrm{CO}$ concentrations reached the highest values during the summer months, with a maximum in July (mean and median value of $0.23 \mathrm{mg} \mathrm{m}^{-3}$ and $0.21 \mathrm{mg} \mathrm{m}^{-3}$, respectively) (Figure 2b), followed by low values during spring and autumn. Another CO peak, slightly lower than summer, was observed during winter, similarly to the PM enhancement (CO monthly mean and median equal, respectively, to $0.16 \mathrm{mg} \mathrm{m}^{-3}$ and $0.16 \mathrm{mg} \mathrm{m}^{-3}$ in December, $0.19 \mathrm{mg} \mathrm{m}^{-3}$ and $0.19 \mathrm{mg} \mathrm{m}^{-3}$ in January, and $0.20 \mathrm{mg} \mathrm{m}^{-3}$ and $0.19 \mathrm{mg} \mathrm{m}^{-3}$ in February). This annual behavior was typical of the biomass burning (BB) effect, due to the occurrence of wildfires in summer and the domestic heating during winter [31,32]. Indeed, despite the remote position, the sampling station was located $3 \mathrm{~km}$ and $4 \mathrm{~km}$ away from the villages of Mammola (approximately 2600 inhabitants) and Grotteria (approximately 3000 inhabitants), respectively, which during the cold season very likely contribute to the $\mathrm{CO}$ emissions through wood stoves [32]. $\mathrm{C}_{6} \mathrm{H}_{6}$ mean value for the whole year was $0.2 \mu \mathrm{g} \mathrm{m}{ }^{-3}$ 
(median: $0.2 \mu \mathrm{g} \mathrm{m}^{-3}$ ). Likewise, higher $\mathrm{C}_{6} \mathrm{H}_{6}$ concentrations, observed during summer and winter seasons (Figure 2c), may be caused by BB. VOCs (i.e., ethane, ethyne, and $\mathrm{C}_{6} \mathrm{H}_{6}$ ) are generally emitted by $\mathrm{BB}$ and they are used to establish the receptor-oriented source apportionment model $[32,58]$. In this study, $\mathrm{C}_{6} \mathrm{H}_{6}$ was analyzed as a $\mathrm{BB}$ tracker, because it is one of the predominant $\mathrm{VOC}$ emissions involved in BB processes [59]. Finally, the BaP showed the maximum values between June and July, and a lower peak in February (Figure 2d). The $\mathrm{BaP}$ is typically released by $\mathrm{BB}$, including the combustion of wood stoves $[32,60]$. During the last decade, the household combustion of biomass, still predominant in small towns [57,61], has been promoted by the European Directive 2009/28/EC as an example of renewable energy, even though it causes an increase of people exposure to $\mathrm{BaP}$ [60]. However, several proposals were offered regarding a sustainable bioenergy [62].

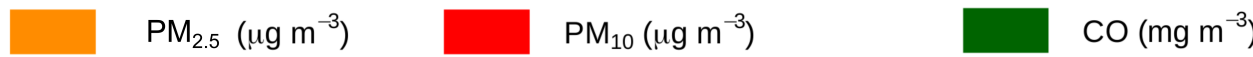

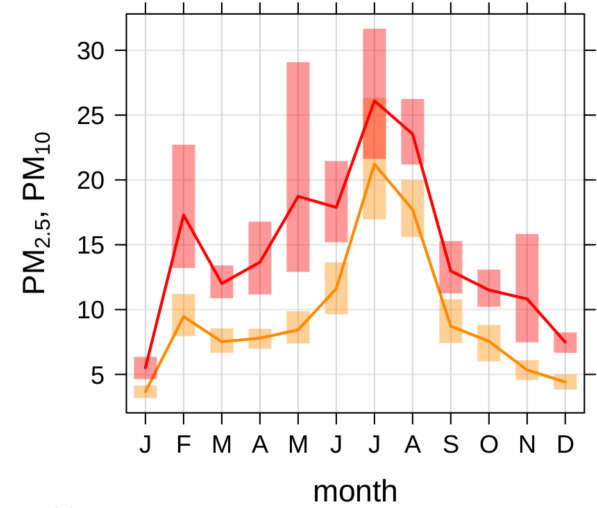

(a) mean value and $95 \%$ confidence interval of values

$\mathrm{C}_{6} \mathrm{H}_{6}\left(\mu \mathrm{g} \mathrm{m}^{-3}\right)$

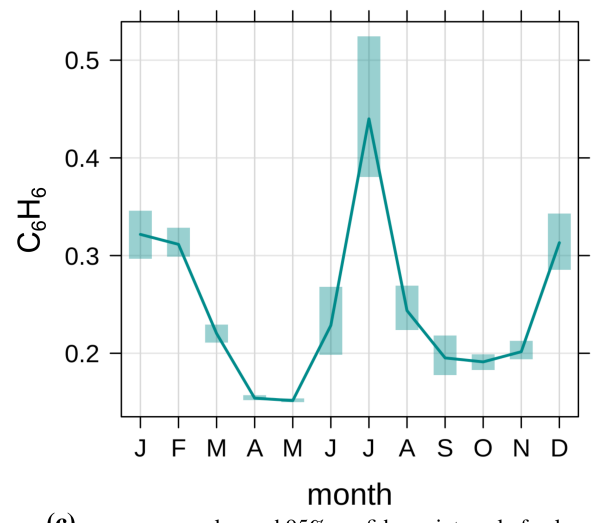

(c) mean value and $95 \%$ confidence interval of values

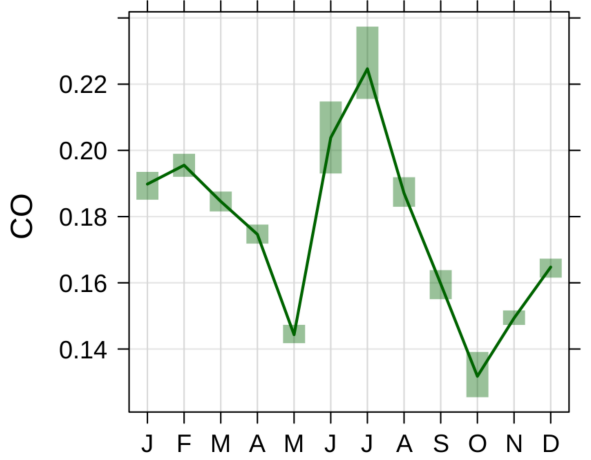

month

(b) mean value and 95\% confidence interval of values

$\operatorname{BaP}\left(\mathrm{ng} \mathrm{m}^{-3}\right)$

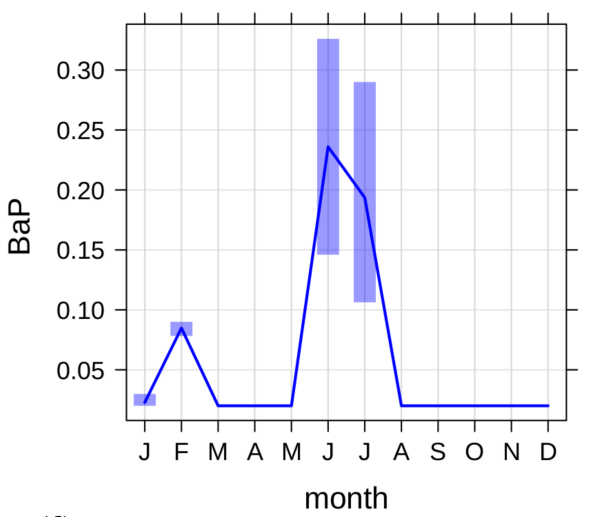

(d) mean value and $95 \%$ confidence interval of values

Figure 2. Monthly variation of (a) $P M_{2.5}$ and $P M_{10}$, (b) $\mathrm{CO}$, (c) $\mathrm{C}_{6} \mathrm{H}_{6}$, and (d) BaP recorded during 2017 at the rural regional background Mammola station. 
The Spearman correlation matrix was calculated for daily $P M_{2.5}, P M_{10}, \mathrm{CO}$, and $\mathrm{C}_{6} \mathrm{H}_{6}$ for the whole year and only for summer (1 June-30 September) (Figure 3). When considering the whole year, the correlation was strong for $P M_{2.5}$ and $P M_{10}(\mathrm{r}=0.90$, $p<0.01)$ and moderate between $\mathrm{CO}$ and $\mathrm{C}_{6} \mathrm{H}_{6}(\mathrm{r}=0.44, p<0.05)$. Moreover, both $P M_{2.5}$ and $\mathrm{PM}_{10}$ were weakly correlated with $\mathrm{CO}$ or $\mathrm{C}_{6} \mathrm{H}_{6}$ (see Figure $3 \mathrm{a}$ for $\mathrm{r}, p<0.01$ for all cases). The cluster analysis calculated through a dendrogram for 2017 highlighted two main clusters: the first with $P M_{2.5}$ and $P M_{10}$ at the smallest distance and the second one that was composed of $\mathrm{CO}$ and $\mathrm{C}_{6} \mathrm{H}_{6}$.

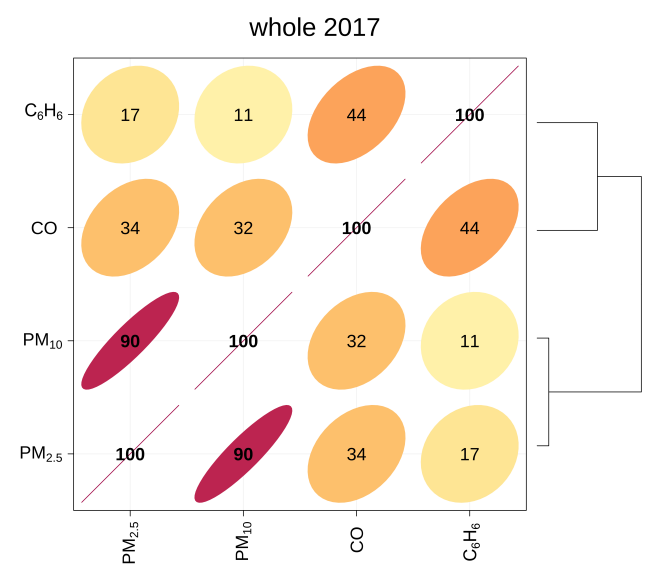

(a)

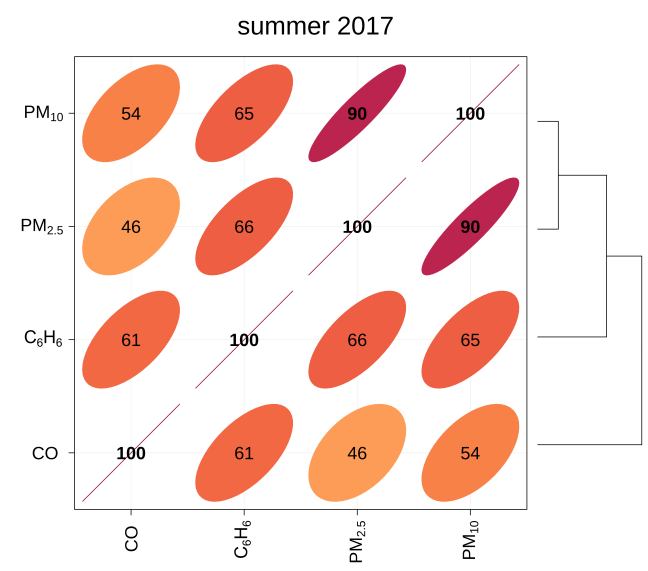

(b)

Figure 3. Spearman matrix correlation and dendrogram among $P M_{2.5}, P M_{10}, \mathrm{CO}$ and $C_{6} H_{6}$ during: (a) the whole 2017, and (b) the summer 2017.

The summer increase of the considered pollutants measured at the Mammola station and the cluster analysis results inspired a study of sources, in this case of natural origins, impacting southern Italy during this season. Figure 4 shows the temporal variation of $P M_{2.5}, P M_{10}, P M_{2.5} / P M_{10}$ ratio, $\mathrm{CO}$, and $\mathrm{C}_{6} \mathrm{H}_{6}$ during summer. For this season, the $P M_{2.5}$ mean value was $14.7 \mu \mathrm{g} \mathrm{m}^{-3}$ (median: $11.6 \mu \mathrm{g} \mathrm{m}^{-3}$ ), while the $P M_{10}$ mean value was $20.0 \mu \mathrm{g} \mathrm{m}^{-3}$ (median: $16.8 \mu \mathrm{g} \mathrm{m}^{-3}$ ). The variability of $P M_{2.5} / P M_{10}$ ratio showed an overall predominant source of fine particulate matter, with few episodes with a prevalence of the coarse-mode. The summer CO mean value was $0.20 \mathrm{mg} \mathrm{m}^{-3}$ (median: $0.18 \mathrm{mg} \mathrm{m}^{-3}$ ). Finally, the $\mathrm{C}_{6} \mathrm{H}_{6}$ mean and median were equal to $0.3 \mu \mathrm{g} \mathrm{m}^{-3}$ and $0.2 \mu \mathrm{g} \mathrm{m}^{-3}$, respectively. During the summer months, the correlations between all of the parameters were generally higher, which suggested a possible more intense influence of a common source with respect to the whole year. $P M_{2.5}$ and $P M_{10}$ were both strongly correlated with $C_{6} H_{6}$ (r equal to 0.66 and $0.65, p<0.01$, respectively) and moderately correlated with $\mathrm{CO}$ ( $\mathrm{r}$ equal to 0.46 and 0.54 , however, it is still $p<0.01$ ), while the correlation between $\mathrm{CO}$ and $\mathrm{C}_{6} \mathrm{H}_{6}$ was substantial (r equal to 0.61, $p<0.01$ ). Moreover, the dendrogram showed that the cluster of $P M_{2.5}$ and $P M_{10}$ created a larger cluster first with $\mathrm{CO}$, and finally with $\mathrm{C}_{6} \mathrm{H}_{6}$. 


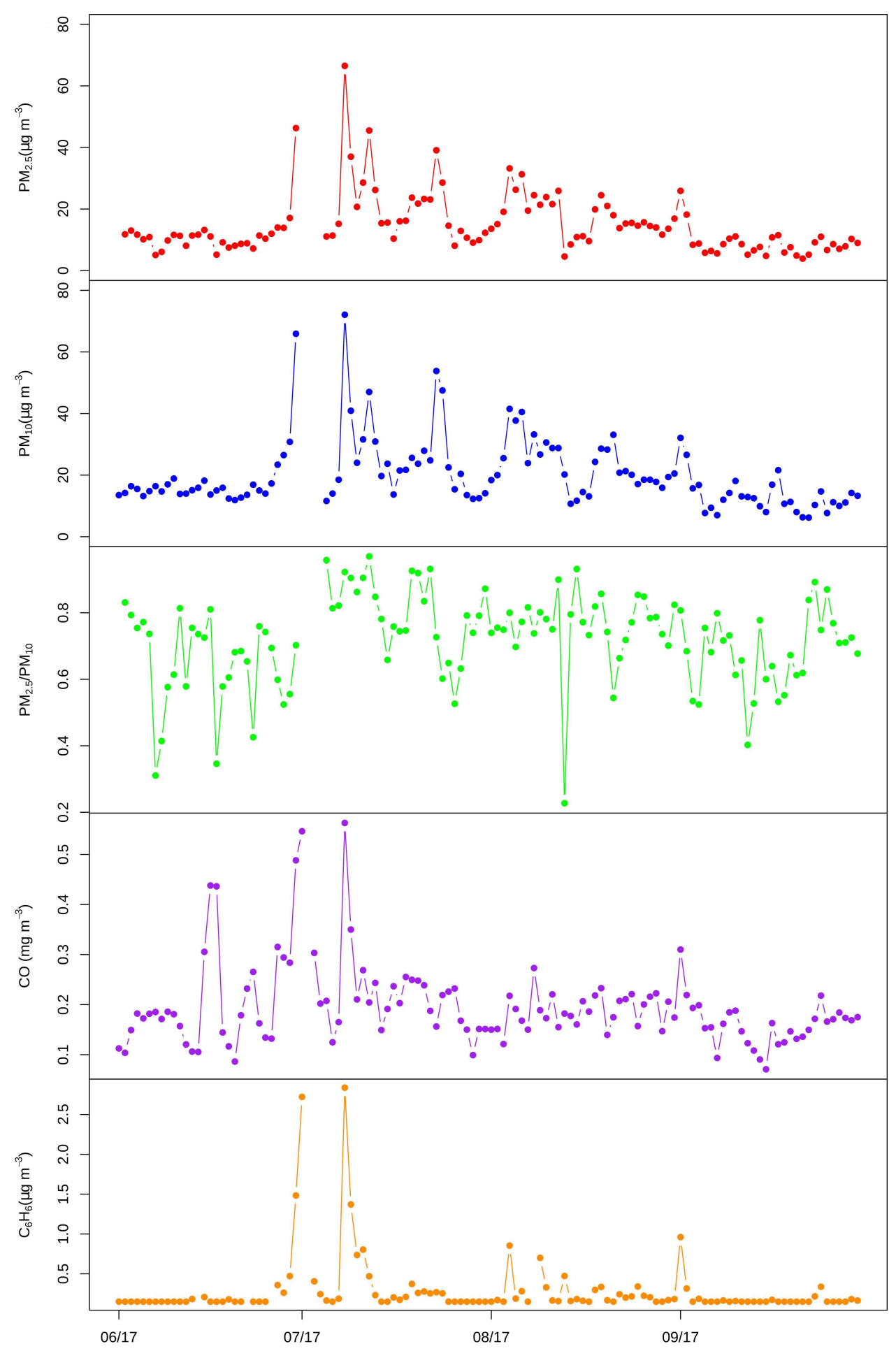

Figure 4. Temporal distribution of $P M_{2.5}, P M_{10}, P M_{2.5} / P M_{10}, C_{6} H_{6}$ and $C O$ recorded at the Mammola station during summer 2017.

\subsection{Saharan Dust Transport}

$120 \mathrm{~h}$ back-trajectories WRF-HYSPLIT ensemble, calculated for the domain, including northern Africa, joined with the dust NAAPS maps, were used in order to establish the advection of Saharan dust (SD) events. Ensemble back-trajectories arriving at the Mammola sampling station (10 m AGL) were calculated every $6 \mathrm{~h}$, while daily NAAPS maps were downloaded at noon UTC. Unlike the western Mediterranean Basin, where the highest frequency of SD intrusions occurs during the summer season, for the central-eastern 
Mediterranean basin these events are rare in this season, while the highest frequency is generally recorded during the winter and spring [12]. Confirming the low frequency of SD for southern Italy during summer $[18,20]$, this case-study revealed only four events for a total of seven days. The first event lasted two days and started on the 29th of June, reaching on 30th of June $65.9 \mu \mathrm{g} \mathrm{m}^{-3}$ and $46.3 \mu \mathrm{g} \mathrm{m}^{-3}$ for $P M_{10}$ and $P M_{2.5}$, respectively. The second event happened between 23rd-25th of July and recorded a peak of $53.8 \mu \mathrm{g} \mathrm{m}^{-3}$ for $P M_{10}$ and $39.1 \mathrm{\mu g} \mathrm{m}^{-3}$ for $P M_{2.5}$. The other two events lasted a day in September (11th and 17th, respectively) and did not show any particular PM increase. Figure 5 shows an example of the ensemble WRF-HYSPLIT back-trajectories that highlights the arrival at the sampling station of air-masses from North-Africa, and the presence of aerosol surface concentration, over southern Italy, estimated as dust by NAAPS model.

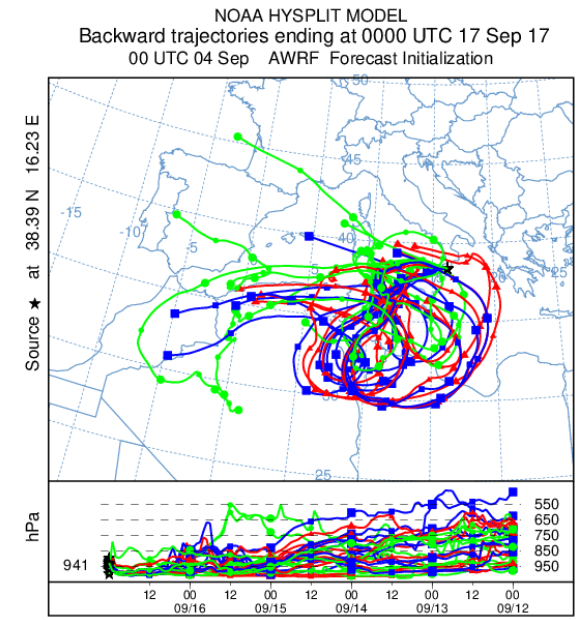

(a)

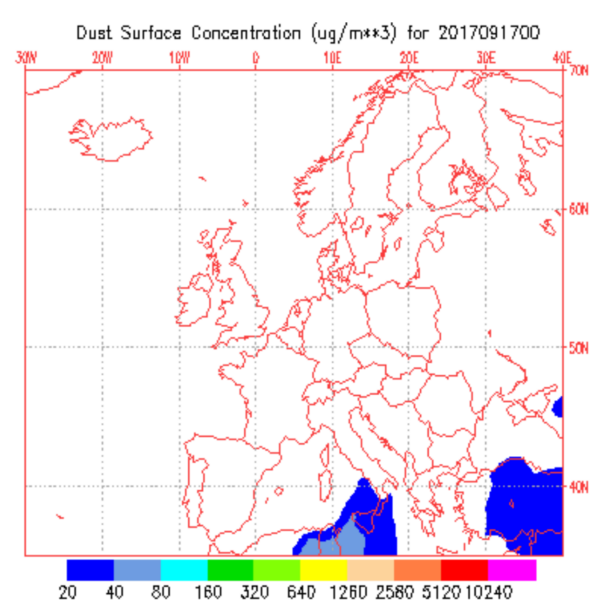

(b)

Figure 5. (a) $120 \mathrm{~h}$ WRF-HYSPLIT back-trajectories ending at the Mammola station and (b) dust Surface Concentration modelled by NAAPS. Both maps refer to 17th of September, 2017.

\subsection{Local and Long-Transported Wildfires Influence}

Because of the higher concentrations of BB pollutants recorded during the summer season, a thorough analysis was conducted in order to evaluate the amount of wildfire influence on the rural regional background station. At first, when at least one parameter among $P M_{2.5}$ and $P M_{10}$ exceeded its 75th percentile (equal to $17.1 \mu \mathrm{g} \mathrm{m}^{-3}, 23.8 \mu \mathrm{g} \mathrm{m}^{-3}$, respectively), an investigation, based on the integration of the high-resolution back-trajectoriescalculated through WRF-HYSPLIT—and the VIIRS data, was conducted [30,63]. VIIRS data were used in order to study the local and long-range transported wildfire sources. Despite the detection limits of satellite data, such as the spatial resolution $(375 \mathrm{~m})$, the missing detection due to the rate of overpassing, and the low detection capability in presence of cloud, smoke, and haze, they have the great advantage of providing global coverage [64]. The required maximum distance to have an enrichment of air-masses was equal to $0.1^{\circ}$ [30]. Figure 6a shows an example of $48 \mathrm{~h}$ ensemble back-trajectories ending at the Mammola station with the identified wildfires (red points). Moreover, the intercepted fire detections through this identification method were confirmed by the smoke NAAPS maps that displayed high concentrations over southern Italy, in particular, over the Mammola sampling area (Figure 6b). 


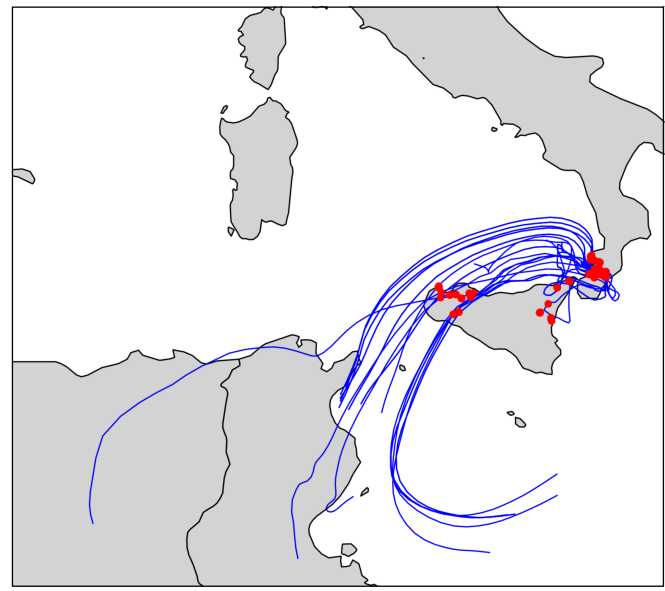

(a)

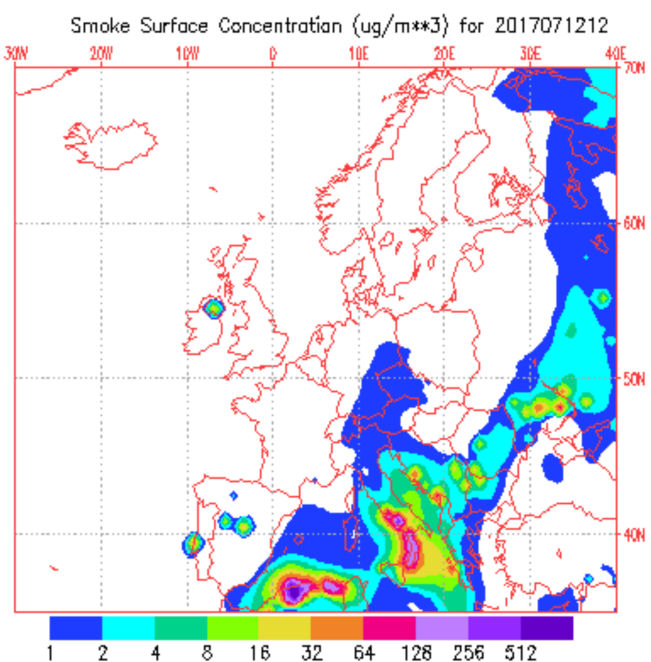

(b)

Figure 6. (a) VIIRS wildfire detections intercepted by the $48 \mathrm{~h}$ WRF-HYSPLIT back-trajectories ending at the Mammola station and (b) Smoke Surface Concentration modelled by NAAPS. Both maps refer to 12 th of July, 2017.

Table 1 shows the monthly and summer days with verified wildfire influence detected at the Mammola sampling station (called as WF Days). The number of wildfire detections (N WF) intercepted by ensemble WRF-HYSPLIT back-trajectories was also reported. Wildfire influence was confirmed for 31 days. The most frequent wildfire events were detected during July and August (with 1245 and 1288 detections in 12 and 14 days, respectively). For June and September, wildfire influence was found only for 2-3 days, with a lower number of detections. In particular, for one day showing also a $\mathrm{C}_{6} \mathrm{H}_{6}$ peak (1st of June), the back-trajectories intercepted a VIIRS thermal anomaly, typed as "land source" located at the Stromboli volcano. This event suggested that the Mammola station, and the area of its representativeness, may also be influenced by volcano emissions, an additional natural source widely present in southern Italy (i.e., Etna, Aeolian islands, and Campi Flegrei).

Table 1. Numbers of days with an identified wildfire influence (WF Days) and related numbers of wildfire detections (N WF) intercepted by ensemble WRF-HYSPLIT back-trajectories. Values are reported for each single month and for the whole summer 2017.

\begin{tabular}{cccc}
\hline & Period of Observation & WF Days & N WF \\
\hline \multirow{3}{*}{ months } & June & 3 & 241 \\
& July & 12 & 1245 \\
& August & 14 & 1288 \\
& September & 2 & 117 \\
\hline \multirow{2}{*}{ summer } & June-September & 31 & 2891 \\
\hline
\end{tabular}

\subsection{Influence of Wildfire and Saharan Dust Events on PM}

Wildfire emissions and Saharan dust intrusions significantly impacted both PM sizes, thus confirming the results observed in other studies for southern Italy [18,20]. Table 2 shows statistics of $P M_{2.5}, P M_{10}$, and their ratio $\left(P M_{2.5} / P M_{10}\right)$ for the whole summer season and considering days with only wildfire influence (called Smoke), with concurrent episodes of wildfires and Saharan dust intrusions (Smoke + SD), with only Saharan dust influence (SD), and, finally, with the only background influence (i.e., without any relevant contribution from specific sources). 
During the smoke days, the $P M_{2.5}$ and $P M_{10}$ mean values increased significantly when compared to BKG days (mean values for $P M_{2.5}$ and $P M_{10}$ for smoke days were $26.1 \mu \mathrm{g} \mathrm{m}^{-3}$ and $32.0 \mu \mathrm{g} \mathrm{m}^{-3}$ against $10.2 \mu \mathrm{g} \mathrm{m}^{-3}$ and $14.8 \mu \mathrm{g} \mathrm{m}^{-3}$, respectively). Furthermore, the recorded ratio between $P M_{2.5}$ and $P M_{10}$ during the smoke days was the highest (0.81) over the examined period due to the higher emission by wildfires into $P M_{2.5}$ size [18]. On the other hand, while wildfires were more impactful on the finer mode, the coarse mode was enhanced by Saharan dust events $[18,20,65]$ as recorded by the lower $P M_{2.5} / P M_{10}$ ratio (0.61) observed when only SD influence was observed. These three Saharan dust recorded days, as highlighted by the lowest recorded $P M_{2.5} / P M_{10}$ ratio, were not intense, as also observed elsewhere during summer, and did not produce a significant amount of mass concentration [18-20,66].

Beyond anthropogenic sources, the events with natural origin, such as wildfires and dust, may impact over air quality, sometimes causing the exceeding of the PM limits $[12,20,67]$. According to the Italian Legislation, D. Lgs. 155/2010, that is an implementation of the European air quality Directive (2008/50/EC), the daily limit for $P M_{10}$ is set to $50 \mu \mathrm{g} \mathrm{m}^{-3}$ (not to be exceeded for more than 35 days per year). On the other hand, official legislative limits for $P M_{2.5}$ do not still exist, but, due to its human health effects, the WHO suggested a threshold equal to $25 \mu \mathrm{g} \mathrm{m} \mathrm{m}^{-3}$ [68].

During summer 2017, the $P M_{10}$ concentration overreached the limit in three days (30th of June, 8th of July, 23rd of July). In respect to natural sources, the evaluation of overreaching $P M_{10}$ concentrations is generally limited only to Saharan dust intrusions. Considering the higher frequency of wildfire occurrences during the summer season in southern Italy [30], in this study-case investigations on both cited natural sources were herein conducted. The cause of the first overreaching $\left(65.9 \mu \mathrm{g} \mathrm{m}^{-3}\right.$ on the 30th of June) was identified as the cumulative effect of the Saharan dust event with the wildfires (daily mean $P M_{2.5} / P M_{10}$ ratio equal to 0.70 ). During the 8th of July, no Saharan dust intrusion was detected, but a number of 48 fire detections were intercepted by the air-masses causing the finer mode increase. Indeed, the recorded $P M_{2.5}$ and $P M_{10}$ were equal to $66.5 \mu \mathrm{g} \mathrm{m}^{-3}$ and $72.1 \mu \mathrm{g} \mathrm{m}^{-3}$, respectively (daily mean $P M_{2.5} / P M_{10}$ ratio equal to 0.92 ). Finally, the daily $P M_{10}$ concentration of the $23 \mathrm{rd}$ of July, equal to $53.8 \mu \mathrm{g} \mathrm{m}^{-3}$, was affected by Saharan dust combined with wildfire emissions (Figure 7). The $P M_{2.5}$ values exceeding the WHO limit were recorded for a total of 15 days, among which three days with the concurrent impact of both wildfires and Saharan dust, and 12 days with only a wildfire influence. $P M_{2.5}$ higher levels are generally associated with anthropogenic influencing sources, and they are also recognized as the most dangerous for human health. When considering the whole period affected by only wildfire events, the $P M_{2.5} / P M_{10}$ ratio was $0.81(0.75-0.90)$ (Table 2). In comparison, for the whole 2017 mean value for the $P M_{2.5} / P M_{10}$ ratio was 0.65, while, for the whole 2017 without summer days, it was 0.61 (Table 2). In Table 3, every single day with a PM exceedance is reported with related PM concentration and ratio value. As shown by Table 3 , the $P M_{2.5} / P M_{10}$ ratio highlighted the greater contribution of the finer particulate size. Indeed, days with $P M_{2.5}$ exceedances influenced only by wildfires displayed ratio values mostly larger than 0.74 . These results suggested that wildfires should raise concern in terms of both prevention and management. In this regard, the effects of human-caused wildfires should be reduced through policies, avoiding ignition and controlling the spread [9]. 


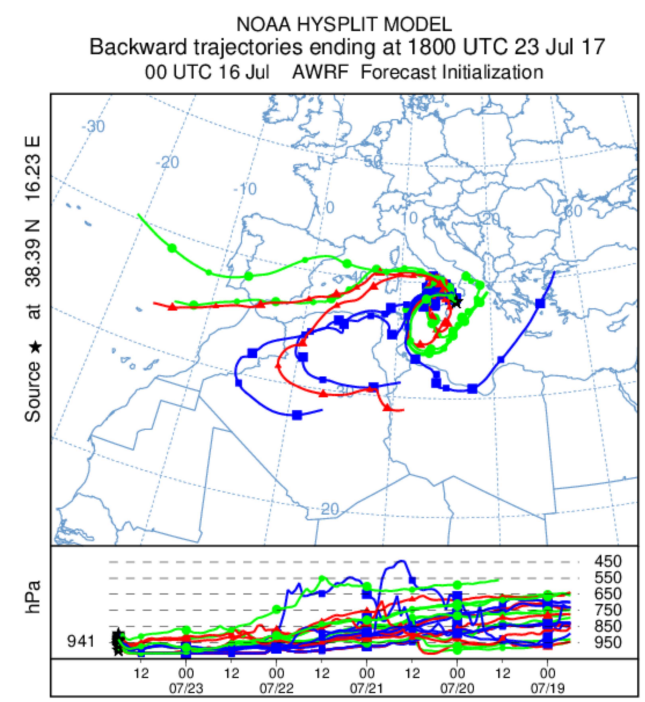

(a)

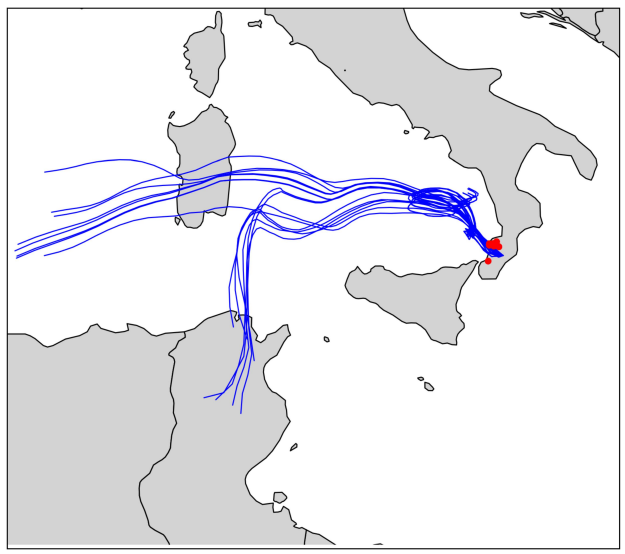

(c)

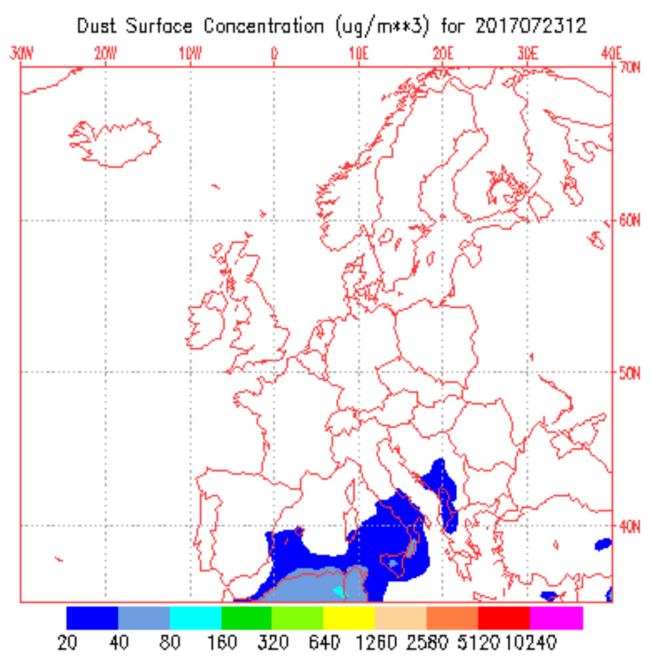

(b)

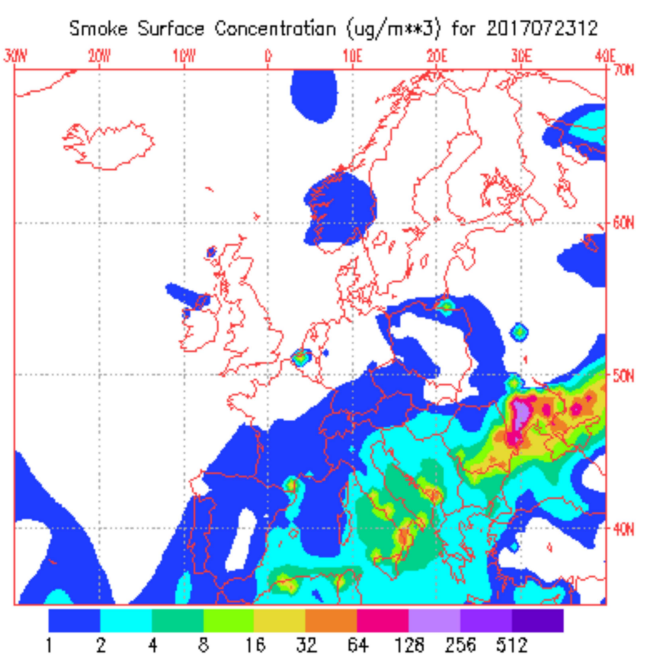

(d)

Figure 7. Concurrent episodes of Saharan dust (SD) confirmed by (a) $120 \mathrm{~h}$ WRF-HYSPLIT backtrajectories and (b) NAAPS dust Surface Concentration, and wildfire (WF) events confirmed by (c) $48 \mathrm{~h}$ WRF-HYSPLIT back-trajectories VIIRS fire detections intercepted and (d) NAAPS Smoke Surface Concentration. All maps refer to 23rd of July, 2017.

Table 2. Statistics of $P M_{2.5}$ and $P M_{10}$ concentrations and their ratio (mean value and 25-75th percentile) for the whole 2017, the whole 2017 without summer, summer season, summer smoke days, summer smoke + SD days, summer SD days, and summer BKG days. For each period, the corresponding number of days (N Days) is also reported.

\begin{tabular}{ccccc}
\hline & N Days & $\boldsymbol{P M}_{\mathbf{2 . 5}}\left(\mu \mathrm{g} \mathrm{m}^{-\mathbf{3}}\right)$ & $\boldsymbol{P M}_{\mathbf{1 0}}\left(\boldsymbol{\mu g} \mathbf{~ m}^{-\mathbf{3}}\right)$ & $\boldsymbol{P M}_{\mathbf{2 . 5}} / \boldsymbol{P M}_{\mathbf{1 0}}$ \\
\hline Whole 2017 & 365 & $9.5(4.9-11.6)$ & $15.0(8.2-16.6)$ & $0.65(0.54-0.76)$ \\
Whole 2017 without summer & 243 & $6.8(4.1-8.3)$ & $12.3(7.5-13.7)$ & $0.61(0.50-0.74)$ \\
Summer & 122 & $14.7(8.7-17.1)$ & $20.0(13.3-23.8)$ & $0.72(0.65-0.80)$ \\
Summer Smoke & 27 & $26.1(20.8-26.2)$ & $32.0(26.0-33.1)$ & $0.81(0.75-0.90)$ \\
Summer Smoke + SD & 4 & $32.8(25.7-40.9)$ & $49.5(43.3-56.8)$ & $0.65(0.59-0.71)$ \\
Summer SD & 3 & $11.6(10.0-13.1)$ & $19.1(17.4-22.1)$ & $0.61(0.59-0.65)$ \\
Summer BKG & 88 & $10.2(8.0-12.2)$ & $14.8(12.4-17.4)$ & $0.70(0.63-0.78)$ \\
\hline
\end{tabular}


Table 3. Exceedances of $P M_{2.5}\left(\mu \mathrm{g} \mathrm{m}^{-3}\right)$ and/or $P M_{10}\left(\mu \mathrm{g} \mathrm{m}^{-3}\right)$ with related $P M_{2.5} / P M_{10}$ ratio and identified source influences. Data are presented with descending order of $P M_{2.5} / P M_{10}$ ratio.

\begin{tabular}{ccccc}
\hline Date & $\boldsymbol{P M}_{\mathbf{2 . 5}}$ & $\boldsymbol{P M}_{\mathbf{1 0}}$ & $\boldsymbol{P M}_{\mathbf{2 . 5}} \boldsymbol{P}_{\mathbf{1 0}}$ & Source \\
\hline 12-07-2017 & 45.5 & 47.0 & 0.97 & Smoke \\
$08-07-2017$ & 66.5 & 72.1 & 0.92 & Smoke \\
11-07-2017 & 28.6 & 31.6 & 0.91 & Smoke \\
$09-07-2017$ & 37.0 & 40.9 & 0.90 & Smoke \\
12-08-2017 & 25.9 & 28.8 & 0.90 & Smoke \\
19-08-2017 & 24.5 & 28.6 & 0.86 & Smoke \\
13-07-2017 & 26.2 & 30.9 & 0.85 & Smoke \\
$01-09-2017$ & 25.9 & 32.1 & 0.81 & Smoke \\
$04-08-2017$ & 33.2 & 41.5 & 0.80 & Smoke \\
$06-08-2017$ & 31.3 & 40.5 & 0.77 & Smoke \\
$08-08-2017$ & 24.5 & 33.2 & 0.74 & Smoke \\
$23-07-2017$ & 39.1 & 53.8 & 0.73 & Smoke + SD \\
30-06-2017 & 46.3 & 65.9 & 0.70 & Smoke + SD \\
05-08-2017 & 26.3 & 37.7 & 0.70 & Smoke \\
24-07-2017 & 28.6 & 47.5 & 0.60 & Smoke + SD \\
\hline
\end{tabular}

\section{Conclusions}

The PM measurements recorded at the Mammola rural regional background station were analyzed to evaluate the impact of some natural sources in southern Italy. The central Mediterranean region is affected by frequent Saharan dust intrusions, depending on the seasonality [12]. Furthermore, during the summer season, a large number of wildfires hits this area, where climate change conditions are exacerbating the extreme events of droughts and heatwaves [3,9]. For the Calabria region, in southern Italy, 2017 was a record year of burned areas by wildfires [27]. This is the reason why the study focused on this year.

At first, the annual variability of all the analyzed parameters was evaluated, highlighting the concentration increase during the summer season. Moreover, while $P M_{10}$ showed a large variability during spring, which may be caused by Saharan dust events, the BB tracing parameters (i.e., $\mathrm{CO}, \mathrm{C}_{6} \mathrm{H}_{6}, \mathrm{BaP}$ ) showed a lower increase during the cold months, which was linkable to the domestic heating. Spearman correlation, among $P M_{2.5}, P M_{10}$, $\mathrm{C}_{6} \mathrm{H}_{6}$, and $\mathrm{CO}$, calculated for the whole year and for the summer season, pointed out the presence of a predominant common source during the summer. Because of the higher monthly concentrations, the investigation of the sources impacting the Mammola station was conducted on the summer period, from the 1st of June to 30th of September.

Later, the adopted methodology was able to identify the Saharan dust intrusion, highlithing seven SD days with concomitant enhancement of $P M_{10}$ concentrations. Moreover, wildfires influence was investigated evaluating the ground-based measurements jointly with VIIRS satellite detections and high-resolution $48 \mathrm{~h}$ WRF-HYSPLIT back-trajectories. The results showed that wildfires affected air quality at the Mammola sampling station for 31 days, with a total amount of 2891 intercepted fires. The most hit month was August, with 14 days, immediately followed by July, with 12 days. During June and September, the wildfires occurrence was reduced to only 2-3 days.

Furthermore, the impact of these natural sources on the PM levels was analyzed. During the summer smoke days, so-called when a wildfire influence was detected, the recorded $P M_{2.5}$ concentrations showed an important increase, as confirmed by the mean $P M_{2.5} / P M_{10}$ ratio being equal to 0.81 . Otherwise, the mean ratio calculated over the whole 2017 was 0.65 , while, over the whole of 2017 without summer days, it was 0.61 . In addition, for 12 out of 15 days with $P M_{2.5}$ exceedances, only the wildfire influence was detected.

Finally, the event with the highest peak in $\mathrm{C}_{6} \mathrm{H}_{6}$ levels also suggested the potential impact of volcanic emissions. Unfortunately, at the current state, there are not enough elements to evaluate a possible contribution of volcano emissions on particulate concentrations. However, this event underlines the importance of atmospheric monitoring accompanied by a thorough chemical characterization of the PM samples in order to ap- 
propriately detect the influencing sources and their relative contribution. In conclusion, this study suggests that among the various and often not-well estimated natural sources affecting southern Italy, such as Saharan dust episodes, volcanic emissions, and wildfires, the latter, which indeed would be better classified as a human-induced source, display risks usually underestimated, representing a troubling concern for consequences on the environment and the human health [6].

Author Contributions: J.C., A.S. and G.M. conceptualized this study; J.C., A.S. and M.B. developed the methodology; J.C. implemented the used software; J.C., A.S. and M.B. conducted the Formal Analysis; J.C. supported by A.S., G.M. and M.B. wrote the Original Draft; all authors conducted the review and editing; G.M. supervised the study. All authors have read and agreed to the published version of the manuscript.

Funding: This work was supported by PAC CALABRIA 2014-2020—Asse Prioritario 12, Azione B) 10.5.12.

Institutional Review Board Statement: Not applicable.

Informed Consent Statement: Not applicable.

Data Availability Statement: Air quality parameters can be downloaded at the following link: https: / / www.eea.europa.eu/data-and-maps/dashboards/air-quality-statistics-expert-viewer.

Acknowledgments: All authors would like to thank the "Agenzia Regionale Protezione Ambiente della Calabria-ARPACAL", in particular the General Director Ing. Domenico Vottari and Pasquale Crea. Moreover, the authors are grateful to Ing. Luca Furnari for the support of model simulations.

Conflicts of Interest: The authors declare no conflict of interest.

\section{References}

1. Commission, E.E. Forest Fires-Sparkling Firesmart Policies in the EU; European Union: Brussels, Belgium, 2018.

2. Feyen, L.; Dankers, R. Impact of global warming on streamflow drought in Europe. J. Geophys. Res. Atmos. 2009, 114, D17116. [CrossRef]

3. Dupuy, J.L.; Fargeon, H.; Martin-StPaul, N.; Pimont, F.; Ruffault, J.; Guijarro, M.; Hernando, C.; Madrigal, J.; Fernandes, P. Climate change impact on future wildfire danger and activity in southern Europe: A review. Ann. For. Sci. 2020, 77, 35. [CrossRef]

4. Johnston, F.H.; Henderson, S.B.; Chen, Y.; Randerson, J.T.; Marlier, M.; DeFries, R.S.; Kinney, P.; Bowman, D.M.; Brauer, M. Estimated global mortality attributable to smoke from landscape fires. Environ. Health Perspect. 2012, 120, 695-701. [CrossRef] [PubMed]

5. Urbanski, S.P.; Hao, W.M.; Baker, S. Chemical composition of wildland fire emissions. Dev. Environ. Sci. 2008, 8, 79-107.

6. Reid, C.E.; Brauer, M.; Johnston, F.H.; Jerrett, M.; Balmes, J.R.; Elliott, C.T. Critical review of health impacts of wildfire smoke exposure. Environ. Health Perspect. 2016, 124, 1334-1343. [CrossRef]

7. Cascio, W.E. Wildland fire smoke and human health. Sci. Total Environ. 2018, 624, 586-595. [CrossRef]

8. Oliveira, M.; Delerue-Matos, C.; Pereira, M.C.; Morais, S. Environmental Particulate Matter Levels during 2017 Large Forest Fires and Megafires in the Center Region of Portugal: A Public Health Concern? Int. J. Environ. Res. Public Health 2020, $17,1032$. [CrossRef]

9. Shukla, P.R.; Skea, J.; Calvo Buendia, E.; Masson-Delmotte, V.; Pörtner, H.-O.; Roberts, D.C.; Zhai, P.; Slade, R.; Connors, S.; van Diemen, R.; et al. (Eds.) Special Report on Climate Change and Land: An IPCC Special Report on Climate Change, Desertification, Land Degradation, Sustainable Land Management, Food Security, and Greenhouse Gas Fluxes in Terrestrial Ecosystems; IPCC: Geneva, Switzerland, 2019.

10. Augusto, S.; Ratola, N.; Tarín-Carrasco, P.; Jiménez-Guerrero, P.; Turco, M.; Schuhmacher, M.; Costa, S.; Teixeira, J.; Costa, C. Population exposure to particulate-matter and related mortality due to the Portuguese wildfires in October 2017 driven by storm Ophelia. Environ. Int. 2020, 144, 106056. [CrossRef]

11. Field, R.D.; Van Der Werf, G.R.; Shen, S.S. Human amplification of drought-induced biomass burning in Indonesia since 1960. Nat. Geosci. 2009, 2, 185-188. [CrossRef]

12. Querol, X.; Pey, J.; Pandolfi, M.; Alastuey, A.; Cusack, M.; Pérez, N.; Moreno, T.; Viana, M.; Mihalopoulos, N.; Kallos, G.; et al. African dust contributions to mean ambient PM10 mass-levels across the Mediterranean Basin. Atmos. Environ. 2009, 43, 4266-4277. [CrossRef]

13. Kok, J.F.; Adebiyi, A.A.; Albani, S.; Balkanski, Y.; Checa-Garcia, R.; Chin, M.; Colarco, P.R.; Hamilton, D.S.; Huang, Y.; Ito, A.; et al. Contribution of the world's main dust source regions to the global cycle of desert dust. Atm. Chem. Phys. Disc. 2021, 1-34. [CrossRef] 
14. Wang, Q.; Gu, J.; Wang, X. The impact of Sahara dust on air quality and public health in European countries. Atmos. Environ. 2020, 241, 117771. [CrossRef]

15. Osborne, M.; Malavelle, F.F.; Adam, M.; Buxmann, J.; Sugier, J.; Marenco, F.; Haywood, J. Saharan dust and biomass burning aerosols during ex-hurricane Ophelia: Observations from the new UK lidar and sun-photometer network. Atmos. Chem. Phys. 2019, 19, 3557-3578. [CrossRef]

16. Bencardino, M.; Sprovieri, F.; Cofone, F.; Pirrone, N. Variability of atmospheric aerosol and ozone concentrations at marine, urban, and high-altitude monitoring stations in southern Italy during the 2007 summer Saharan dust outbreaks and wildfire episodes. J. Air Waste Manag. Assoc. 2011, 61, 952-967. [CrossRef]

17. Pey, J.; Querol, X.; Alastuey, A.; Forastiere, F.; Stafoggia, M. African dust outbreaks over the Mediterranean Basin during 2001-2011: PM10 concentrations, phenomenology and trends, and its relation with synoptic and mesoscale meteorology. Atmos. Chem. Phys. 2013, 13, 1395. [CrossRef]

18. Bencardino, M.; Andreoli, V.; D’Amore, F.; Simone, F.D.; Mannarino, V.; Castagna, J.; Moretti, S.; Naccarato, A.; Sprovieri, F.; Pirrone, N. Carbonaceous Aerosols Collected at the Observatory of Monte Curcio in the Southern Mediterranean Basin. Atmosphere 2019, 10, 592. [CrossRef]

19. Calidonna, C.R.; Avolio, E.; Gullì, D.; Ammoscato, I.; Pino, M.D.; Donateo, A.; Feudo, T.L. Five Years of Dust Episodes at the Southern Italy GAW Regional Coastal Mediterranean Observatory: Multisensors and Modeling Analysis. Atmosphere 2020, 11, 456. [CrossRef]

20. Conte, M.; Merico, E.; Cesari, D.; Dinoi, A.; Grasso, F.; Donateo, A.; Guascito, M.; Contini, D. Long-term characterisation of African dust advection in south-eastern Italy: Influence on fine and coarse particle concentrations, size distributions, and carbon content. Atmos. Res. 2020, 233, 104690. [CrossRef]

21. Stohl, A. Computation, accuracy and applications of trajectories-a review and bibliography. Atmos. Environ. 1998, 32, 947-966. [CrossRef]

22. Stohl, A.; Haimberger, L.; Scheele, M.; Wernli, H. An intercomparison of results from three trajectory models. Meteorol. Appl. 2001, 8, 127-135. [CrossRef]

23. Stohl, A.; Forster, C.; Frank, A.; Seibert, P.; Wotawa, G. The Lagrangian particle dispersion model FLEXPART version 6.2. Atm. Chem. Phys. Disc. 2005, 5, 2461-2474. [CrossRef]

24. Fleming, Z.L.; Monks, P.S.; Manning, A.J. Untangling the influence of air-mass history in interpreting observed atmospheric composition. Atmos. Res. 2012, 104, 1-39. [CrossRef]

25. Stein, A.; Draxler, R.R.; Rolph, G.D.; Stunder, B.J.; Cohen, M.; Ngan, F. NOAA's HYSPLIT atmospheric transport and dispersion modeling system. Bull. Am. Meteorol. Soc. 2015, 96, 2059-2077. [CrossRef]

26. Skamarock, W.C.; Klemp, J.B.; Dudhia, J.; Gill, D.O.; Barker, D.M.; Wang, W.; Powers, J.G. A Description of the Advanced Research WRF Version 3; NCAR Technical note-475+ STR; UCAR: Boulder, CO, USA, 2008; 113p.

27. Castagna, J.; Senatore, A.; Bencardino, M.; Colosimo, F.; D'Amore, F.; Sprovieri, F.; Siviglia, S.; Pirrone, N.; Mendicino, G. Longtime dataset of wildfires in the Calabria Region (southern Italy) during the period 2008-2019 and a case-study dataset of specific air quality tracers and meteorological measurements recorded at the Monte Curcio GAW station during summer 2017. Data Brief 2020, in submission.

28. EC. COMMISSION STAFF WORKING PAPER establishing guidelines for demonstration and subtraction of exceedances attributable to natural sources under the Directive 2008/50/EC on ambient air quality and cleaner air for Europe. Off. J. Eur. Union L 2011.

29. Christensen, J.H. The Danish Eulerian hemispheric model-A three-dimensional air pollution model used for the Arctic. Atmos. Environ. 1997, 31, 4169-4191. [CrossRef]

30. Castagna, J.; Senatore, A.; Bencardino, M.; D’Amore, F.; Sprovieri, F.; Pirrone, N.; Mendicino, G. Multiscale assessment of the impact on air quality of an intense wildfire season in southern Italy. Sci. Total Environ. 2020, 761, 143271. [CrossRef]

31. Wang, T.; Cheung, T.; Li, Y.; Yu, X.; Blake, D. Emission characteristics of CO, NOx, SO2 and indications of biomass burning observed at a rural site in eastern China. J. Geophys. Res. Atmos. 2002, 107, ACH-9. [CrossRef]

32. Chen, J.; Li, C.; Ristovski, Z.; Milic, A.; Gu, Y.; Islam, M.S.; Wang, S.; Hao, J.; Zhang, H.; He, C.; et al. A review of biomass burning: Emissions and impacts on air quality, health and climate in China. Sci. Total Environ. 2017, 579, 1000-1034. [CrossRef]

33. Agenzia Regionale Della Protezione Ambientale (ARPACAL). Available online: http://www.arpacal.it/ (accessed on 31 December 2020).

34. Larssen, N.; Sluyter, R.; Helmis, C. Criteria for EUROAIRNET. The EEA, Air Quality Monitoring and Information Network; EEA: Copenhagen, Denmark, 1999.

35. Air Quality e-Reporting-Environment Agency (EEA). Available online: https://www.eea.europa.eu/data-and-maps/data/ aqereporting-8 (accessed on 31 December 2020).

36. Schroeder, W.; Oliva, P.; Giglio, L.; Csiszar, I.A. The New VIIRS $375 \mathrm{~m}$ active fire detection data product: Algorithm description and initial assessment. Remote Sens. Environ. 2014, 143, 85-96. [CrossRef]

37. Senatore, A.; Mendicino, G.; Knoche, H.R.; Kunstmann, H. Sensitivity of modeled precipitation to sea surface temperature in regions with complex topography and coastlines: A case study for the Mediterranean. J. Hydrometeorol. 2014, 15, 2370-2396. [CrossRef] 
38. Furnari, L.; Mendicino, G.; Senatore, A. Hydrometeorological Ensemble Forecast of a Highly Localized Convective Event in the Mediterranean. Water 2020, 12, 1545. [CrossRef]

39. Senatore, A.; Davolio, S.; Furnari, L.; Mendicino, G. Reconstructing flood events in Mediterranean coastal areas using different reanalyses and high-resolution meteorological models. J. Hydrometeorol. 2020, 21, 1865-1887. [CrossRef]

40. Senatore, A.; Furnari, L.; Mendicino, G. Impact of high-resolution sea surface temperature representation on the forecast of small Mediterranean catchments' hydrological responses to heavy precipitation. Hydrol. Earth Syst. Sci. 2020, 24, 269-291. [CrossRef]

41. CESMMA-Department of Environmental Engineering of the University of Calabria. Available online: https://cesmma.unical. it/cwf/ (accessed on 31 December 2020).

42. Avolio, E.; Cavalcanti, O.; Furnari, L.; Senatore, A.; Mendicino, G. Brief communication: Preliminary hydro-meteorological analysis of the flash flood of 20 August 2018 in Raganello Gorge, southern Italy. Nat. Hazards Earth Syst. Sci. 2019, 19, 1619-1627. [CrossRef]

43. Tiedtke, M. A comprehensive mass flux scheme for cumulus parameterization in large-scale models. Mon. Weather Rev. 1989, 117, 1779-1800. [CrossRef]

44. Draxler, R.R.; Taylor, A.D. Horizontal dispersion parameters for long-range transport modeling. J. Appl. Meteorol. Climatol. 1982, 21,367-372. [CrossRef]

45. Draxler, R.R.; Hess, G. An overview of the HYSPLIT_4 modelling system for trajectories. Aust. Meteorol. Mag. 1998, 47, 295-308.

46. Castagna, J.; Bencardino, M.; D'Amore, F.; Esposito, G.; Pirrone, N.; Sprovieri, F. Atmospheric mercury species measurements across the Western Mediterranean region: Behaviour and variability during a 2015 research cruise campaign. Atmos. Environ. 2018, 173, 108-126. [CrossRef]

47. Diéguez, M.C.; Bencardino, M.; García, P.E.; D’Amore, F.; Castagna, J.; De Simone, F.; Cárdenas, C.S.; Guevara, S.R.; Pirrone, N.; Sprovieri, F. A multi-year record of atmospheric mercury species at a background mountain station in Andean Patagonia (Argentina): Temporal trends and meteorological influence. Atmos. Environ. 2019, 214, 116819. [CrossRef]

48. Hybrid Single-Particle Lagrangian Integrated Trajectory Model (HYSPLIT). Available online: https:/ / www.ready.noaa.gov / HYSPLIT_traj.php (accessed on 31 December 2020).

49. Rolph, G.; Stein, A.; Stunder, B. Real-time environmental applications and display system: READY. Environ. Model. Softw. 2017, 95, 210-228. [CrossRef]

50. Yerramilli, A.; Dodla, V.B.R.; Challa, V.S.; Myles, L.; Pendergrass, W.R.; Vogel, C.A.; Dasari, H.P.; Tuluri, F.; Baham, J.M.; Hughes, R.L.; et al. An integrated WRF/HYSPLIT modeling approach for the assessment of PM 2.5 source regions over the Mississippi Gulf Coast region. Air Qual. Atmos. Health 2012, 5, 401-412. [CrossRef] [PubMed]

51. Liu, N.; Yu, Y.; He, J.; Zhao, S. Integrated modeling of urban-scale pollutant transport: Application in a semi-arid urban valley, Northwestern China. Atmos. Pollut. Res. 2013, 4, 306-314. [CrossRef]

52. Sari, D.; Incecik, S.; Ozkurt, N. Analysis of surface ozone episodes using WRF-HYSPLIT model at Biga Peninsula in the Marmara region of Turkey. Atmos. Pollut. Res. 2020, 11, 2361-2378. [CrossRef]

53. Hogan, T.F.; Rosmond, T.E. The description of the Navy Operational Global Atmospheric Prediction System's spectral forecast model. Mon. Weather Rev. 1991, 119, 1786-1815. [CrossRef]

54. Hogan, T.F.; Brody, L.R. Sensitivity studies of the Navy's global forecast model parameterizations and evaluation of improvements to NOGAPS. Mon. Weather Rev. 1993, 121, 2373-2395. [CrossRef]

55. Navy Operational Global Atmospheric Prediction System (NOGAPS). Available online: https://www.nrlmry.navy.mil/aerosol/ (accessed on 31 December 2020).

56. ARPACAL. Allegato 4-Capitolato Tecnico Prestazionale Lotto 1, Procedura Aperta per L'acquisizione di Servizi e Forniture per la Rete Regionale di Monitoraggio della Qualità dell'aria Della Regione Calabria; Agenzia Regionale per la Protezione dell'Ambiente della Calabria: Catanzaro, Italy; 77p.

57. Pavese, G.; Calvello, M.; Castagna, J.; Esposito, F. Black carbon and its impact on air quality in two semi-rural sites in Southern Italy near an oil pre-treatment plant. Atmos. Environ. 2020, 233, 117532. [CrossRef]

58. Petracchini, F.; Romagnoli, P.; Paciucci, L.; Vichi, F.; Imperiali, A.; Paolini, V.; Liotta, F.; Cecinato, A. Influence of transport from urban sources and domestic biomass combustion on the air quality of a mountain area. Environ. Sci. Pollut. Res. 2017, 24, 4741-4754. [CrossRef]

59. Guo, H.; Wang, T.; Simpson, I.; Blake, D.; Yu, X.; Kwok, Y.; Li, Y. Source contributions to ambient VOCs and CO at a rural site in eastern China. Atmos. Environ. 2004, 38, 4551-4560. [CrossRef]

60. Guerreiro, C.; Horálek, J.; de Leeuw, F.; Couvidat, F. Benzo (a) pyrene in Europe: Ambient air concentrations, population exposure and health effects. Environ. Pollut. 2016, 214, 657-667. [CrossRef]

61. Nava, S.; Lucarelli, F.; Amato, F.; Becagli, S.; Calzolai, G.; Chiari, M.; Giannoni, M.; Traversi, R.; Udisti, R. Biomass burning contributions estimated by synergistic coupling of daily and hourly aerosol composition records. Sci. Total Environ. 2015, 511, 11-20. [CrossRef] [PubMed]

62. Fritsche, U.R.; Hennenberg, K.; Hünecke, K.; Herrera, R.; Wiegmann, K. Sustainable Bioenergy: Key Criteria and Indicators; Final D; Oeko-Institut: Freiburg, Germany, 2012.

63. Castagna, J.; Calvello, M.; Esposito, F.; Pavese, G. Analysis of equivalent black carbon multi-year data at an oil pre-treatment plant: Integration with satellite data to identify black carbon transboundary sources. Remote Sens. Environ. 2019, $235,111429$. [CrossRef] 
64. Giglio, L.; Randerson, J.T.; van der Werf, G.R. Analysis of daily, monthly, and annual burned area using the fourth-generation global fire emissions database (GFED4). J. Geophys. Res. Biogeosci. 2013, 118, 317-328. [CrossRef]

65. Pederzoli, A.; Mircea, M.; Finardi, S.; Di Sarra, A.; Zanini, G. Quantification of Saharan dust contribution to PM10 concentrations over Italy during 2003-2005. Atmos. Environ. 2010, 44, 4181-4190. [CrossRef]

66. Meloni, D.; Di Sarra, A.; Biavati, G.; DeLuisi, J.; Monteleone, F.; Pace, G.; Piacentino, S.; Sferlazzo, D. Seasonal behavior of Saharan dust events at the Mediterranean island of Lampedusa in the period 1999-2005. Atmos. Environ. 2007, 41, 3041-3056. [CrossRef]

67. Gobbi, G.P.; Angelini, F.; Barnaba, F.; Costabile, F.; Baldasano Recio, J.M.; Basart, S.; Sozzi, R.; Bolignano, A. Changes in particulate matter physical properties during Saharan advections over Rome (Italy): A four-year study, 2001-2004. Atmos. Chem. Phys. 2013, 13, 7395-7404. [CrossRef]

68. World Health Organization. WHO Air Quality Guidelines for Particulate Matter, Ozone, Nitrogen Dioxide and Sulphur Doixide, Global Update 2005. Summary of Risk Assessment; WHO: Geneva, Switzerland, 2006. 